\title{
Porodaedalea (Phellinus pini group, Basidiomycetes) in Europe: a new species on Larix sibirica, P. niemelaei
}

\author{
MICHAEL FISCHER
}

\begin{abstract}
FISCHER, M. 2000: Porodaedalea (Phellinus pini group, Basidiomycetes) in Europe: a new species on Larix sibirica, P. niemelaei. - Karstenia 40: 43-48. Helsinki. ISSN 0453-3402.

Two specimens of Porodaedalea (Phellinus pini group, Basidiomycetes), collected from Larix sibirica in Finland, were compared with the European-based species P. pini and $P$. chrysoloma, and other taxa originating from North America, Russia, and China. While differentiation based on fruiting-body characters was difficult, pairing tests and sequence data of the nuclear ribosomal ITS region (ITS-1, 5.8S, ITS-2) showed the collections from Larix sibirica to be distinct and they are suggested as a new species, Porodaedalea niemelaei M. Fischer.
\end{abstract}

Key words: Pairing tests, Phellinus pini group, Porodaedalea, Porodaedalea niemelaei, sequence analysis

Michael Fischer, Institut für Botanik, Universität Regensburg, D-93040 Regensburg, Germany. E-mail: michael.fischer@biologie.uni-regensburg.de

\section{Introduction}

"Phellinus, with its many complexes of closely related species, seems to be still in a strong evolutionary stage" (Ryvarden 1991). One of these still unresolved, problematic groups is that of Phellinus pini (Brot. : Fr.) Ames and its relatives, usually referred to as the $P$. pini group. In a comprehensive study on the European poroid Hymenochaetales, the $P$. pini group was raised by Fiasson and Niemelä (1984) to generic level, as Porodaedalea Murrill. This taxonomic status was accepted by, for instance, Nuss (1986) and Jahn and Jahn (1986); it was not followed by Gilbertson and Ryvarden (1987), Parmasto (1988), Larsen and Cobb-Poulle (1990), and Ryvarden and Gilbertson (1994). Recently, an intermediate concept has been developed by Dai (1999), who attributes a subgeneric rank to the $P$. pini group, i.e., Phellinus subg. Porodaedalea (Murrill) Y.C. Dai. The concept of Fiasson and Niemelä, which is derived from an array of 20 different characters of the fruiting-body and the mycelium, correlates well with several sets of molecular data (Fischer 1996; unpubl. data); therefore, the designation
Porodaedalea instead of $P$. pini group is used in this paper.

Porodaedalea has a worldwide distribution, having been reported from a variety of conifers in Europe, North America, Asia, and Africa. A number of closely related taxa, most of them not separable by morphological and/or anatomical features of the fruiting-body, are known to exist worldwide. However, only the type species, $P$. pini (Brot. : Fr.) Murrill, and $P$. chrysoloma (Fr.) Fiasson \& Niemelä, are generally recognized and included in the respective handbooks. The possible existence of additional taxa in North America and Asia has been suggested by Percival (1933), Owens (1936), Overholts (1953), and Parmasto (1985). As a consequence, several taxa related to Porodaedalea have been introduced during the last years: Porodaedalea piceina (Peck) Niemelä (Niemelä 1985), Phellinus vorax (Harkness) Cerný (Cerný 1985), P. cancriformans (M.J. Larsen et al.) M.J. Larsen \& Lombard (Larsen \& Cobb-Poulle 1990), as well as P. himalayensis Y.C. Dai and P. yamanoi (Imazeki) Parmasto (Dai 1999). 
Pairing tests of single-spore isolates from 54 samples collected in Europe, North America, Asia, and Africa demonstrated the existence of numerous intersterile taxa within Porodaedalea, most of them probably host-specific (Fischer 1994). Apart from P. pini and P. chrysoloma, both restricted to Europe, seven intersterility groups, including P. piceina (Niemelä 1985), were demonstrated for North America, three intersterility groups for Asia, and one for North Africa (Morrocco). Within the non-European intersterility groups of Porodaedalea, a distinct morphological and/or anatomical differentiation is preceded by the formation of reproductive barriers. Later on, the results obtained by pairing tests were essentially confirmed by RFLPs (restriction fragment length polymorphisms) of an enzymatically amplified portion of the nuclear RNA genes (Fischer 1996).

Both pairing tests and RFLPs support the traditional view that only two taxa of Porodaedalea exist in Europe. While P. pini seems restricted to species of Pinus (Jahn 1963; Kreisel of P. chrysoloma from Abies, Larix, and Pinus mugo or $P$. sylvestris (Bourdot \& Galzin 1928; Jahn 1967; Cerný 1985) may be questionable. In Europe, I have found only species of Pinus and Picea abies as hosts for $P$. pini and $P$. chrysoloma, respectively.

Fungus-host relationships seem to be of considerable importance in speciation of parasitic lignicolous basidiomycetes, a prominent case being that of Heterobasidion annosum (Fr.) Bref., where the existing intersterility groups have been demonstrated to be largely host-specific (Chase \& Ullrich 1985; Korhonen et al. 1989; Niemelä \& Korhonen 1998). In Phellinus, three intersterile taxa, two of them host specific, were found to exist within P. igniarius as defined by Niemelä (1975). So, host range of lignicolous basidiomycetes deserves special attention.

In 1994 and 1995, Tuomo Niemelä sent two fruiting-bodies of Porodaedalea, both collected on the same tree of Larix sibirica at different times in Finland. These collections, 94-617 and TN 5877, representing different ontogenetic stages, were examined as follows: An integrative approach was used, which was based on the fruiting-body characters, pairing tests with selected tester strains, and a molecular sequence analysis of the nuclear ribosomal ITS region (ITS-1, 5.8S, ITS-2). Special emphasis was on the comparison with well defined material of $P$. pini and $P$. chrysoloma. Two more specimens originating from Larix, collected in China and Russia, and representing intersterility groups As-II and As-III (Fischer 1994), as well as specimens from Picea glauca (Canada; representing P. piceina) and Pinus muricata (U.S.A.; representing intersterility group $\mathrm{N}-\mathrm{VI}$ ), were also included.

\section{Materials and methods}

Specimens examined: Porodaedalea pini (Brot. : Fr.) Murrill: Germany, Bavaria, on Pinus sylvestris, 12.VII.1984 - 84-71. Finland, Satakunta prov., on Pinus sylvestris, 24.IV.1994 - TN 5749.

Porodaedalea chrysoloma (Fr.) Fiasson \& Niemelä: Finland, on Picea abies, 24.VI.1987 - TN 4008. Germany, Bavaria, on Picea abies, 8.IV.1989 - 89-67.

Porodaedalea piceina (Peck) Niemelä: Canada, Quebec, on Picea glauca, 24.IX.1987 - 87-001 (三N-I in Fischer 1994).

Specimens of uncertain affinity: Finland, PohjoisHäme prov., on Larix sibirica, 17.VI.1994 - 94-617; 20.VIII.1995 - TN 5877. U.S.A., California, on Pinus muricata, 22.III.1991 - 91-109 (三 N-VI in Fischer 1994). Russia, Siberia, on Larix dahurica, IX $1990-$ 151400 ( $\equiv$ As-II in Fischer 1994). China, Jilin prov., Chanbaishan, on Larix olgensis, 12.X.1991 - P-86 (三 As-III in Fischer 1994).

Cultural conditions: All cultures were grown on ME medium ( $2 \%$ agar, $2 \%$ malt extract, $0.05 \%$ yeast extract) at $23^{\circ} \mathrm{C}$ and $65 \%$ humidity.

Isolation of single spores: A section of the hymenium was attached to the lid of a Petri plate. Discharged spores were dispersed with Ringer's solution $(\mathrm{NaCl}$, $0.25 \% ; \mathrm{KCl}, 0.01 \% ; \mathrm{CaCl}, 0.005 \% ; \mathrm{NaHCO}_{3}, 0.005 \%$ in distilled $\mathrm{H}_{2} \mathrm{O}$ ) and aseptically isolated after germination.

Pairing tests and comparative microscopy: Pairing tests and microscopy were performed as described in Fischer (1994). Three distinct types of reactions were distinguished in intra-strain pairings: 1) Selfing resulted in intermingling of mycelia; 2) formation of a line of demarcation was observed in pairings of incompatible isolates $(\mathrm{A}=) ; 3)$ development of a secondary mycelium was observed in pairings of compatible isolates $(A \neq)$.

DNA isolation: DNA was isolated from fresh and lyophilized mycelium. Isolation was essentially as described by Lee and Taylor (1990). DNA pellets were resuspended in $10 \mu \mathrm{TE}$ buffer $(10 \mathrm{mM}$ Tris- $\mathrm{HCl}, 1 \mathrm{mM}$ EDTA, pH 8.0). Concentration of DNA was examined in $1 \%$ agarose gels.

Polymerase chain reaction $(P C R)$ : The PCR was used to amplify a portion of the nuclear ribosomal DNA unit defined by the primer combination ITS1 and ITS4 (for primer sequences, see White et al. 1990). The fragment spans the entire region of the internal transcribed spacers, i.e., ITS-1 and ITS-2, as well as the 5.8S rRNA gene.

The PCR reactions were set up in $100 \mu \mathrm{l}$ volumes and were overlayed with two drops of mineral oil. Hot start PCR was applied throughout (d'Aquila et al. 1991). Thirty-seven cycles were performed on a Biometra TRIO-Thermoblock, using the following parameters: $94^{\circ} \mathrm{C}$ denaturation step $(1 \mathrm{~min} 30 \mathrm{~s}), 53^{\circ} \mathrm{C}$ annealing 
step (45 s), $72^{\circ} \mathrm{C}$ primer extension ( $1 \mathrm{~min} 30 \mathrm{~s}$ ). A final incubation step at $72^{\circ} \mathrm{C}(7 \mathrm{~min})$ was added after the final cycle. Five $\mu \mathrm{l}$ of each PCR reaction were electrophoresed on $1 \%$ agarose gels. DNA molecular weight marker VI (Boehringer, Mannheim) was used as standard. The amplified products were purified with the QIAquick PCR Purification Kit (Qiagen) following the manufacturer's instructions. DNA was suspended in $50 \mu \mathrm{l}$ Tris- $\mathrm{HCl}$ buffer (10 mM, pH 8.0).

Sequencing: Fragments were sequenced with the AmpliTaq DNA Polymerase FS Dye Terminator Cycle Sequencing kit (Perkin Elmer), using $2 \mu 1$ of premix, $1 \mu 1$ of the primers ( 8 pmol of ITS1 and ITS4, respectively), and $3.5 \mu \mathrm{l}$ of the PCR products. The reactions were set up in $11 \mu 1$ volumes, and were overlayed with a drop of mineral oil.

Sequences were generated in two directions and twenty-five amplification cycles were carried out, using the following parameters: $96^{\circ} \mathrm{C}$ denaturation step $(30 \mathrm{~s})$, $59^{\circ} \mathrm{C}$ annealing step (15 s) for ITS $1,53^{\circ} \mathrm{C}$ annealing step (15 s) for ITS4, $60^{\circ} \mathrm{C}$ primer extension (4 min). DNA was precipitated by addition of $2 \mu \mathrm{l}$ of $\mathrm{NaAc}(3 \mathrm{M}$, $\mathrm{pH} 4.8$ ) and $55 \mu \mathrm{l}$ of $\mathrm{EtOH} 100 \%$, and was then washed with $150 \mu \mathrm{l}$ of EtOH $70 \%$. The DNA pellet was resuspended in EDTA $(50 \mathrm{mM}$, pH 8.0) : formamide $=1: 4$.

The electrophoresis was done with an ABI 373A Automatic Sequencer (Perkin Elmer). After processing the raw data with SeqEd (version 3.0), the sequences were aligned using the CLUSTAL W (version 1.6) program (Thompson et al. 1994). A final alignment was performed by eye. Alignment gaps were treated as missing data.

For neighbor joining analysis, a distance matrix was generated using DNA DIST, a program from the PHYLIP 3.5c package (Felsenstein 1993). The calculation was performed using the Kimura 2 model and a transition-transversion ratio of 1.5. Bootstrap values for internal nodes were calculated by 1000 replications using the programs SEQBOOT and CONSENSE.

\section{Results}

\section{Pairing tests}

Strains 94-617 and TN 5877 originate from the same tree of Larix sibirica; the mycelia isolated from the fruiting-bodies intermingled when paired and so were assignable to one single individual.

A sufficient number of single spore isolates were obtained from TN 5877, and intra-strain pairing tests using eight single spore isolates demonstrated a unifactorial pattern of sexuality. Corresponding results were obtained for the other strains under study (for details, see Fischer 1994).

For inter-strain pairings two different isolates per mating type factor were selected from each strain as testers; these were paired in all combinations. The results of the inter-strain pairings showed TN 5877 to be reproductively isolated and only intersterile results were obtained in pairings involving single spore testers of TN 5877 (Table 1).

\section{Sequencing}

The size of the rDNA portion defined by the primer combination ITS1 and ITS4 was slightly variable and ranged between 681 (strain 151400) and 691 ( $P$. chrysoloma) nucleotides. No intraspecific variation was observed. Length variations between taxa were due to several small length mutations (insertions and deletions) in the ITS- 1 and ITS-2 region; the size of these mutations ranged between one and three nucleotides. The total length of the alignment was 694 nucleotides.

The phylogenetic tree generated by the neighbor-joining analysis is subdivided into three clades (Fig. 1). The European species, Porodaedalea pini and $P$. chrysoloma, came out as distinctly separated. Strongly supported by a bootstrap value of $100 \%$, P. pini appeared as sister group to the North American taxa, P. piceina, from Picea glauca, and intersterility group N-VI, from Pinus muricata. Strains originating from Larix were unified in a single clade (bootstrap

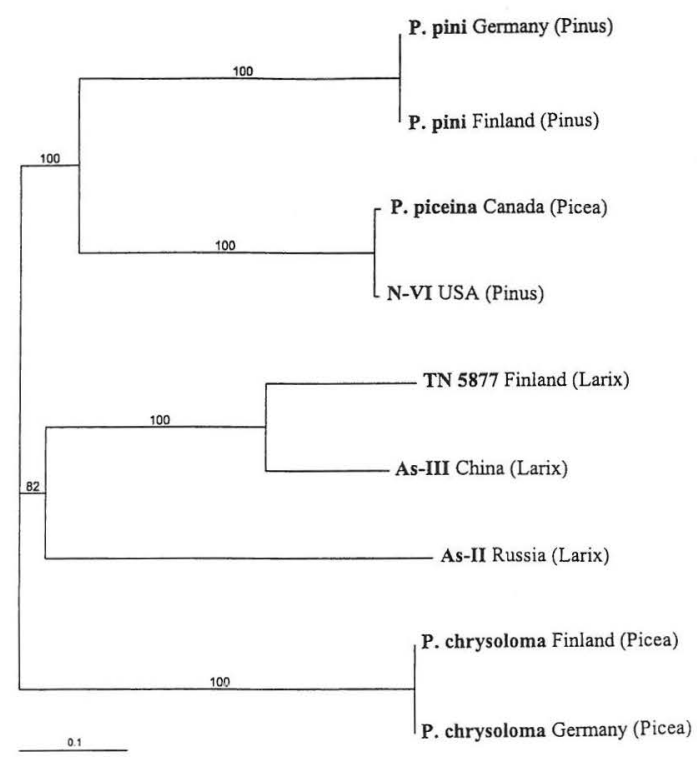

Fig. 1. Relationships between taxa of Porodaedalea (Phellinus pini group) from Europe, North America and Asia inferred from the nuclear ITS region (ITS-1, 5.8S, ITS-2) using the neighbor joining method. Support from 1000 bootstrap replications indicated above the branches. 
value $82 \%$ ). Within this clade, TN 5877 was positioned next to the Chinese strain, P-86, from Larix olgensis (bootstrap value 100\%); the Russian strain, 151400, from Larix dahurica, was separated by a long branch length.

\section{Measurements of spores and setae}

Spores were ellipsoid to subglobose in P. pini, mostly subglobose in P. chrysoloma, and ellipsoid to subglobose in TN 5877 and 94-617. According to the size of basidiospores and hymenial setae, no unequivocal differentiation was possible between $P$. pini and $P$. chrysoloma. On the average, $P$. pini had somewhat larger spores, $4-5.5(-6) \times 2.5-4.5(-5) \mu \mathrm{m}$, and setae, $(14-) 16-$ $54(-58) \times 5-15 \mu \mathrm{m}$, than $P$. chrysoloma, with spores of (3-)3.5-4.5 $\times 2.5-4 \mu \mathrm{m}$ and setae of (15-)20-42(-45) × (3-)4-11(-15) $\mu \mathrm{m}$. As shown before, there is, however, some overlap between these taxa (Fischer 1996).

Even though belonging to one single individual, spore sizes were not uniform for 94-617 and TN 5877. In 94-617, representing a large and more massive fruiting body, spore dimensions were (5.5-)6-7 × (4.5-)5-5.5 $\mu \mathrm{m}$; in TN 5877, representing a younger specimen, spores were smaller, (4.5-)5-6 × (3.5-)4-4.5(-5) $\mu \mathrm{m}$. The size of the hymenial setae was (15-)20-45(-50) $\times$ (4-)5-11 $\mu \mathrm{m}$ for both collections. Thus, basidiospores of the Finnish strains on Larix are slightly larger than those of $P$. pini and $P$. chrysoloma; setal dimensions are similar to those of P. chrysoloma.

For the Chinese strain from Larix olgensis, P-86, spores were found to be distinctly smaller, 3.5-4 × 2.5-3.5 $\mu \mathrm{m}$, setae resembled those of P. chrysoloma and were $25-50 \times 5-10 \mu \mathrm{m}$. Since no fruiting-bodies were available for strain 151400 , from Larix dahurica, no data can be provided here.

\section{Taxonomic conclusions}

Taken together, the characters examined in this study demonstrate a distinct taxonomic position of TN 5877 and 94-617; therefore, these collections are suggested to represent a new species:

Porodaedalea niemelaei M. Fischer, spec. nov.

Basidiomata perennia, effuso-reflexa ad pileata; superficies rubrobrunnea ad atra, concen- trice sulcata, irregulariter fracta et sero incrustata. Superficies pororum luteobrunnea ad rubiginosa, pori circulares vel plus minusve daedaleoidei, (1-)2-3 in quoque millimetro. Contextus rubiginosus, lignosus durus, ca. $5 \mathrm{~mm}$ crassus; tubuli juvenes luteoli, deinde rubiginosi, ad $1.5 \mathrm{~cm}$ longi, sero cum contexto fusi; systema hypharum dimiticum; omnia septa fibulis egentia; hyphae skeletales luteobrunneae, 2.5-3.5 um latae; setae frequentes in hymenio, plerumque subulatae, raro ventricosae, (15-)

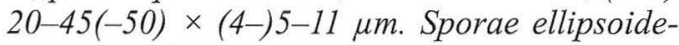
ae ad subglobosae, hyalinae, tenui vel modice crassitunicatae, modice cyanophilicae, inamyloideae, $(4.5-) 5-6(-7) \times(3.5-) 4-5(-5.5) \mu \mathrm{m}$.

Fruiting-bodies perennial, effused-reflexed to pileate; pileal surface reddish brown to black, concentrically sulcate, irregularly cracked and becoming encrusted with age; pore surface yellowish brown to rust brown, pores circular to more or less daedaleoid, (1-)2-3 per mm; context rust brown, woody hard, ca. $5 \mathrm{~mm}$ thick; tubes yellowish when young, becoming rust brown with age, up to $1.5 \mathrm{~cm}$ long, old tubes merging into context; hyphal system dimitic; all septa without clamp connections, skeletal hyphae yellowish brown, 2.5-3.5 $\mu$ m wide; setae frequent in the hymenium, mostly subulate, rarely ventricose, $(15-) 20-45(-50) \times(4-) 5-11 \mu \mathrm{m}$; spores ellipsoid to subglobose, hyaline, thin- to slightly thick-walled, slightly cyanophilous, inamyloid, (4.5-)5-6(-7) × (3.5-)4-5(-5.5) $\mu \mathrm{m}$.

Holotype: Finland, South-Häme, Juupajoki, Hyytiälä, on living tree of Larix sibirica, 20.VIII.1995 T. Niemelä 5877 (REG).

\section{Discussion}

The data presented in this study demonstrate that besides $P$. pini and $P$. chrysoloma another taxon of Porodaedalea exists in Europe. The Finnish strain TN 5877, originating from Larix sibirica, was sharply delimited by pairing tests and molecular sequences of the ribosomal ITS region (Table 1; Fig. 1). With respect to characters of the fruiting-body, the differentiation remains more questionable. In both collections of $P$. niemelaei, hymenial setae were similar to those of $P$. chrysoloma. Basidiospores were larger than those in P. pini and P. chrysoloma, but, although belonging to one single individual, some varia- 
Table 1. Porodaedalea in Europe, North America, and Asia: Pairings of single spore testers.

\begin{tabular}{|c|c|c|c|c|c|c|c|}
\hline & P. pini & P. chrysoloma & TN 5877 & P. piceina & $\mathrm{N}-\mathrm{VI}$ & As-II & As-III \\
\hline $\begin{array}{l}\text { P. pini } \\
\text { (Europe) }\end{array}$ & $50^{\mathrm{a}}$ & - & - & $(-)$ & $(-)$ & - & - \\
\hline $\begin{array}{l}\text { P. chrysoloma } \\
\text { (Europe) }\end{array}$ & & 50 & - & - & - & - & - \\
\hline $\begin{array}{l}\text { TN } 5877 \\
\text { (Europe) }\end{array}$ & & & 50 & - & - & - & - \\
\hline $\begin{array}{l}\text { P. piceina } \\
\text { (Canada) }\end{array}$ & & & & 50 & $(-)$ & - & - \\
\hline $\begin{array}{l}\text { N-VI } \\
\text { (U.S.A.) }\end{array}$ & & & & & 50 & - & - \\
\hline $\begin{array}{l}\text { As-II } \\
\text { (Russia) }\end{array}$ & & & & & & 50 & - \\
\hline $\begin{array}{l}\text { As-III } \\
\text { (China) }\end{array}$ & & & & & & & 50 \\
\hline
\end{tabular}

${ }^{a}$ bifactorial pattern of sexuality in intra-strain pairings $=50$; intersterility complete $=-$; intersterility incomplete $=(-)$.

tion of the spore size was noted among the specimens. Additional collections of $P$. niemelaei are needed to elucidate this phenomenon. In general, spores and setae of $P$. pini and P. chrysoloma as observed in this study were smaller than those reported by Cerný (1985), Ryvarden and Gilbertson (1994), and, in part, Jülich (1984). However, the data provided in the literature are problematical since they may have been based on different taxa.

The geographic distribution of $P$. niemelaei in Europe remains unclear. Possibly the taxon is restricted to autochthonous stands of Larix in Northern and Central Europe. Reports of Porodaedalea on Larix are very rare; such findings have been mentioned by Jahn (1976), Cerny (1985), and Breitenbach and Kränzlin (1986). Very recently, I have reexamined a putative locality of $P$. cf. pini on Larix decidua near Innsbruck, Austria, but without any success.

No strict correlation between the molecular data on one hand and geographic or host criteria on the other hand is evident in the phylogenetic tree (Fig. 1). The North American taxa, P. piceina and N-VI, originate from different host genera, but appear as very close sister groups. In these taxa, divergence of ribosomal sequences is preceded by the establishment of far-reaching reproductive isolation (Table 1; Fischer 1994). The
European species, $P$. pini and $P$. chrysoloma, came out as clearly separated genetically. In other respects these taxa are well-defined as well. Collections of $P$. pini and $P$. chrysoloma usually can be distinguished by their substrate, the shape of fruiting-bodies and the dimensions of spores and setae. Consequently, $P$. pini and $P$. chrysoloma may be considered as phylogenetically old taxa. The strains from Larix, albeit of different geographic origin, are unified in one clade. Fruiting-bodies of the Chinese collection from Larix olgensis have distinctly smaller spores than $P$. niemelaei. Nevertheless, these taxa exhibit similar ITS sequences. This is another case, where reproductive isolation and - possibly - anatomical differentiation precede a distinct diversity of molecular data.

As has been indicated before (Niemelä 1985; Fischer 1994, 1996), P. piceina represents a separate species, next related to the North American intersterility group N-VI. While fruiting-bodies of $P$. piceina occur saproparasitically on Picea glauca, P. mariana and, less often, on Larix laricina (Niemelä 1985), strains belonging to N-VI all originate from living trees of Pinus muricata (Fischer 1994). Additional taxa, so far undescribed, exist in Asia. Dai (1999) cites four species of Porodaedalea (as Phellinus subg. Porodaedalea) as occurring in East Asia: Phellinus 
himalayensis, $P$. cf. laricis (Jaczewski in Pilát) Pilát, P. cf. pini, and P. yamanoi. With the data at hand, the exact relationships of strains P-86 (China, Larix olgensis, As-II) and 151400 (Russia, Larix dahurica, As-III) to these taxa remain uncertain. The spores of P-86, 3.5-4 × 2.5-3.5 $\mu \mathrm{m}$, are distinctly smaller than any dimensions reported by Dai (1999). Probably the closest relative is Phellinus cf. laricis, which was reported from species of Larix including Larix olgensis and other hosts; however, spores are bigger in this taxon, 4.1-5.2 × 3.5-4.5 $\mu \mathrm{m}$ (Dai 1999).

Acknowledgments: Many thanks go to Dr. Tuomo Niemelä, who over the years provided me with numerous collections of lignicolous basidiomycetes. For this study, additional specimens were sent by Drs. Erast Parmasto and Wolfgang Paulus. I am grateful to Dr. Walter Gams for critically reading the manuscript and providing the Latin diagnosis.

\section{References}

Bourdot, H. \& Galzin, A. 1928: Hyménomycètes de France. - Paul Lechevalier, Paris, France. 761 pp.

Cerný, A. 1985: Taxonomic study in the Phellinus pini group. - Ceská Mykol. 39: 71-84.

Chase, T.E. \& Ullrich, R.C. 1985: Genetics of intersterility in Heterobasidion annosum. - Mycol. Soc. Amer. Newslett. 36: 20.

Dai, Y.C. 1999: Phellinus sensu lato (Aphyllophorales, Hymenochaetaceae) in East Asia. - Acta Botanica Fennica 166: 1-115.

D’Aquila, R.T., Bechtel, L.J., Videler, J.A., Eron, J.E. Gorczyca, P. \& Kaplan, J.C. 1991: Maximizing sensitivity and specificity of PCR by preamplification heating. - Nucleic Acids Res. 19: 3749.

Felsenstein J. 1993: Phylip version 3.5c. - Distributed by the University of Washington, Seattle.

Fiasson, J.L. \& Niemelä, T. 1984: The Hymenochaetales: a revision of the European poroid taxa. Karstenia 24: 14-28.

Fischer, M. 1994: Pairing tests in the Phellinus pini group.- Mycologia 86: 524-539.

Fischer, M. 1996: Molecular and microscopical studies in the Phellinus pini group. - Mycologia 88: 230- 238.

Gilbertson, R.L. \& Ryvarden, L. 1987: North American polypores. Vol. 2. - Fungiflora, Oslo, Norway. 450 pp.

Jahn, H. 1963: Mitteleuropäische Porlinge (Polyporaceae s.l.) und ihr Vorkommen in Westfalen (unter Ausschluß der resupinaten Arten). - Westfäl. Pilzbriefe 4: 1-143.

Jahn, H. 1967: Die resupinaten Phellinus-Arten in Mitteleuropa. - Westfäl. Pilzbriefe 6: 37-108.

Jahn, H. \& Jahn, M.A. 1986: Konstanz und Fluktuation der Pilzvegetation in Norra Warleda (Uppland). Beobachtungen auf einem schwedischen Bauernhof. Westfäl. Pilzbriefe 10-11: 352-378.

Jülich, W. 1984: Die Nichtblätterpilze, Gallertpilze und Bauchpilze. - G. Fischer, Stuttgart, New York. 626 pp.
Korhonen, K., Capretti, P., Moriondo, F. \& Mugnai L. 1989: A new breeding group of Heterobasidion annosum found in Europe. - Proceedings of the $7^{\text {th }}$ international conference on root and but rots. Victoria, Canada: 20-26.

Kreisel, H. 1987: Pilzflora der Deutschen Demokratischen Republik. - G. Fischer, Jena, Germany. 281 pp.

Larsen, M.J. \& Cobb- Poulle, L.A. 1990: Phellinus (Hymenochaetaceae). A survey of the world taxa. - Fungiflora, Oslo, Norway. 206 pp.

Lee, S.B. \& Taylor, J.W. 1990: Isolation of DNA from fungal mycelia and single cells. - In: Innis, M.A., Gelfand, D.H., Sninsky, J.J. \& White, T.J. (eds.), PCR protocols: 282-287. Academic Press, San Diego, USA.

Niemelä, T. 1975: On Fennoscandian polypores 4. Phellinus igniarius, P. nigricans and P. populicola, n. sp. - Ann. Bot. Fennici 12: 93-122.

Niemelä, T. 1985: Mycoflora of Poste-de-la-Baleine, northern Quebec. Polypores and the Hymenochaetales. - Naturaliste Canad. 112: 445-472.

Niemelä, T. \& Kotiranta, H. 1982: Polypore survey of Finland 2. The genus Phellinus. - Karstenia 22: 27-42.

Niemelä, T. \& Korhonen, K. 1998: Taxonomy of the genus Heterobasidion. - In: Heterobasidion annosum. Biology, Ecology, Impact and Control: 27-33. CAB International, Wallingford, UK.

Nuss, I. 1986: Zur Ökologie der Porlinge. II - Bibliotheca Mycologica 105: 1-469.

Overholts, L.O. 1953: The Polyporaceae of the United States, Alaska, and Canada. - University of Michigan Press, Ann Arbor. 446 pp.

Owens, C.E. 1936: Studies on the woodrotting fungus Fomes pini. Variation in morphology and growth habit. - Amer. J. Bot. 23: 144-149.

Parmasto, E. 1985: Species concept in Hymenochaetaceae (Fungi, Hymenomycetes). - Proc. Indian Acad. Sci. 94: 369-380.

Parmasto, E. 1988: What is Ochroporus ossatus (Hymenochaetaceae)? - Mycotaxon 32: 219-222.

Percival, W.C. 1933: A contribution to the biology of Fomes pini (Thore) Lloyd (Trametes pini [Thore] Fries). - Bull. New York State Coll. Forest. 6: 1-72.

Ryvarden, L. 1991: Genera of polypores. - Fungiflora, Oslo, Norway. 363 pp.

Ryvarden, L. \& Gilbertson, R.L. 1994: European Polypores. Part 2. - Fungiflora, Oslo, Norway. 355 pp.

Thompson J.D., Higgins, D.G. \& Gibson, T.J. 1994: Clustal W: improving the sensitivity of progressive multiple sequence alignment through sequence weighting, position specific gap penalties and weight matrix choice. - Nucleic Acids Res. 22: 4673-4680.

White T.J, Bruns, T.D., Lee, S. \& Taylor, J.W. 1990: Amplification and direct sequencing of fungal ribosomal RNA genes for phylogenetics. - In: Innis, M.A., Gelfand, D.H., Sninsky, J.J. \& White, T.J. (eds.), PCR protocols: 315-322. Academic Press, San Diego, USA. 